Check for updates

New York

Cite this as: BMJ 2021;372:n232 http://dx.doi.org/10.1136/bmj.n232 Published: 26 January 2021

\title{
Covid-19: Moderna plans booster doses to counter variants
}

\section{Janice Hopkins Tanne}

The US drug company Moderna has announced that it is developing two new approaches to emerging variants of covid-19 after studies showed that its vaccine had a reduced level of neutralising titres to the South African variant, suggesting that immunity might wane.

Although the studies showed that Moderna's current vaccine, known as mRNA-1273, was effective against both the UK and South African variants, a sixfold reduction was seen in neutralising titre levels to the South African variant. ${ }^{1}$

Moderna said that "out of an abundance of caution" it was starting a clinical programme of two booster approaches to increase immunity to the new variants. Moderna's chief executive officer, Stéphane Bancel, said, "We believe it is imperative to be proactive as the virus evolves."

In the first approach Moderna said that it would see whether a third "booster dose" of the current mRNA-1273 vaccine added to the approved two dose regimen would further increase neutralising titres against the emerging variants.

In a second approach the company said that it had developed a booster vaccine candidate called mRNA-1273.351 against the emerging South African variant. It said that it was beginning phase I studies in the US to see whether this modified vaccine with variant specific proteins would increase the immunological effect.

In an interview with The BMJ earlier this month Andrew Pollard, a leader of the Oxford-AstraZeneca vaccine trials, explained that modifying the vaccine was not complicated. "For the RNA vaccines and the viral vectors it's relatively straightforward, because you just have to synthesise a new bit of DNA in our case-or RNA in [the Pfizer and Moderna] cases-and then insert that into the new vaccine. Then there's a bit of work to do to manufacture the new vaccine, which is a reasonably heavy lift. But the same processes would be used."2

\section{Trial groups}

Moderna developed its current vaccine in 42 days. The new approach may be ready by the autumn, and authorisation by the Food and Drug Administration may be quicker than the long phase I, II, and III trials required for a new vaccine.

Bancel told the Financial Times that a few thousand trial participants for the new approaches would be divided into two groups. One would receive a booster third dose of the original two dose vaccine, while a second group would receive the new booster vaccine, mRNA-1273.351. ${ }^{3}$

The UK variant has eight mutations in the spike protein that the virus uses to attach to human cells, and the South African variant has 10 mutations. Both variants have spread rapidly, are more infectious, and cause a higher viral burden after infection. Another variant, found in Brazil, shares many mutations with the South African variant.

In an attempt to slow the variants' spread, US President Joe Biden has banned entry into the US by people from the UK, the European Union, Brazil, and South Africa if they are not US citizens. Already the UK variant has been identified in at least 20 states in the US. The Brazil variant was identified on 25 January in a Minnesota resident who had recently returned from Brazil.

As of last night the US has reported more than 25 million cases of covid-19, nearly 130 ooo new cases, more than 1800 new deaths, and more than 110 ooo people now in hospital. More than 400 ooo people in the US have died from covid-19. ${ }^{4}$

President Biden, who promised a million vaccinations a day-which seems to have been achieved-has now raised the goal to 1.5 million vaccinations a day.

\section{In vitro study}

The Moderna vaccine's efficacy was supported by an in vitro study posted on the preprint server bioRxiv. It showed that Moderna's current vaccine, mRNA-1273, "elicited potently neutralizing antibodies” against the UK and South African variants. The study has not been peer reviewed. ${ }^{5}$

In the study, investigators from Moderna and the Vaccine Research Center of the US National Institute of Allergy and Infectious Diseases used serum samples from eight people who had received two 100 microgram doses of mRNA-1273 and, separately, serum samples from non-human primates that had received two doses of 30 micrograms or 100 micrograms of mRNA-1273.

In the UK variant, neutralising antibody titres were high and were generally consistent with the neutralising titres seen with prior variants. In the South African variant, the vaccine produced neutralising antibody titres that were above the neutralising titres that protected non-human primates against wild-type viral challenge.

Moderna said in a press release, "While the company expects these levels of neutralizing antibodies to be protective, neutralizing antibody titers were approximately six-fold lower relative to prior variants. These lower titers may suggest a potential risk of earlier waning of immunity to the new [South African] B.1.351 strains.”

Moderna. Moderna covid-19 vaccine retains neutralizing activity against emerging variants first identified in the UK and the Republic of South Africa. 25 Jan 2021. https://investors.modernatx.com/node/10841/pdf.

2 Mahase E. How the Oxford-AstraZeneca covid-19 vaccine was made. BMJ 2021;372:n86. doi: 10.1136/bmj.n86. pmid: 33436419 
3 Kuchler H. Moderna develops new vaccine to tackle mutant covid strain. Financial Times 2021 Jan 25. https://www.ft.com/content/c0c8f72c-e58e-4319-80c4-0db153ad85db.

4 Coronavirus in the US. Latest map and case count. New York Times 2021 Jan 25. https://www.nytimes.com/interactive/2020/us/coronavirus-us-cases.html.

5 Wu K, Werner AP, Moliva II, et al. mRNA-1273 vaccine induces neutralizing antibodies against spike mutants from global SARS-CoV-2 variants. bioRxiv [preprint] 2021 Jan 25. https://www.biorxiv.org/content/10.1101/2021.01.25.427948v1.

This article is made freely available for use in accordance with BMI's website terms and conditions for the duration of the covid-19 pandemic or until otherwise determined by BMJ. You may use, download and print the article for any lawful, non-commercial purpose (including text and data mining) provided that all copyright notices and trade marks are retained. 